\title{
2. CRETACEOUS CHALKS BENEATH NEOGENE VOLCANIC CLAYS, EAST OF THE JAPAN TRENCH: DSDP SITE 194
}

\author{
The Shipboard Scientific Party ${ }^{1}$
}

\section{SITE DATA}

Occupied: 19-22 Sept 1971

Position: Abyssal floor east of Japan; lat $33^{\circ} 58.7^{\prime} \mathrm{N}$

long $148^{\circ} 48.6^{\prime} \mathrm{E}$

Water Depth: 5744 meters

Number of Cores: 5

Total Penetration: 256 meters

Deepest Unit Recovered: Massive Upper Cretaceous cherts of the opaque acoustic layer; basement not reached.

Main Results: The upper transparent layer consists mainly of late Tertiary silty radiolarian clays. The opaque layer is formed of massive cherts and softer sediments. Cretaceous Radiolaria were recovered by the bit from the cherty section. The cherts were not successfully penetrated and basement was not reached.

\section{BACKGROUND}

The generalized acoustic stratigraphy of the western Pacific employed by several workers consists of: (1) transparent (transaural), (2) opaque, (3) lower transparent, and (4) acoustic basement or flat acoustic basement "b." For a few hundred kilometers eastward of the Japan Trench the lower transparent layer is not observed and, therefore, it is not possible to ascertain if the opaque layer is absent or lies directly on acoustic basement. Site 194 (Figures 1,2) offered some hopes of resolving this problem, for at this location previous seismic reflection records had indicated the appearance of stratification within, or just above, what might otherwise be considered acoustic basement.

The only previous results which might give an indication of what to expect were provided by Deep Sea Drilling Sites 51 and 52 . At Site 51, a clearly defined lower transparent layer lies beneath the opaque layer, and a plausible interpretation of the seismic records in the region suggests that as the lower transparent layer thins out to the west, the opaque layer lies directly on basement. Thus, the first

\footnotetext{
${ }^{1}$ Bruce C. Heezen, Lamont-Doherty Geological Observatory; Ian D. MacGregor, University of California, Davis; Helen P. Foreman, Oberlin College; George Forristall, Eidgenössische Technische Hochschule, Zürich; H. Hekel, Queensland Geological Survey, Brisbane; Reinhard Hesse, Technische Hochschule, Munich; Robert H. Hoskins, New Zealand Geological Survey, Lower Hutt; E. John W. Jones, University College, London; Ansis Kaneps, Scripps Institution of Oceanography, La Jolla; Valeri A. Krasheninnikov, Academy of Sciences, Moscow; Hakuyu Okada, Kagoshima University, Japan; Michael H. Ruef, Washington Department of Ecology, Olympia.
}

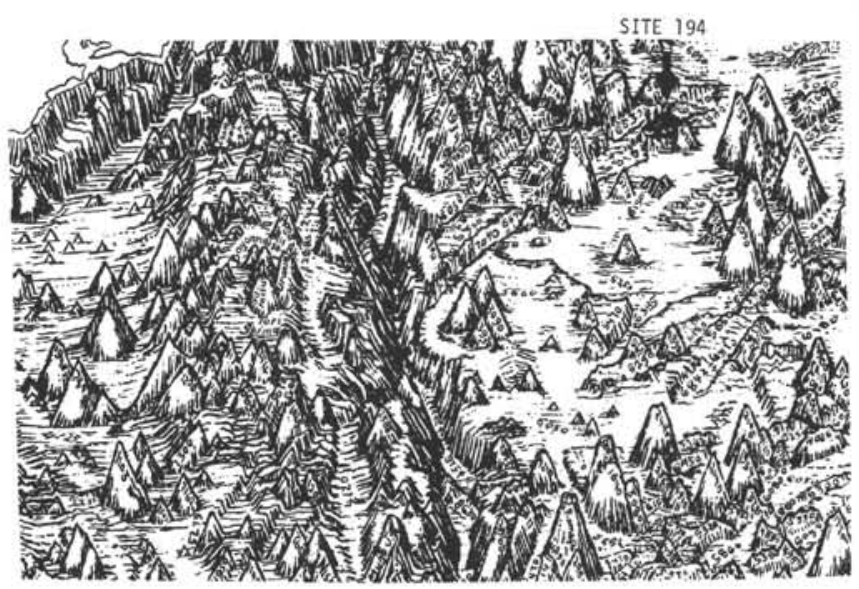

Figure 1. Location of Site 194.

strong reflectors at Site 194 (Figure 3) could be expected to be the same massive, Cretaceous chert which had terminated drilling at Site 51 . The deepest reflector could be expected to be igneous basement or perhaps highly

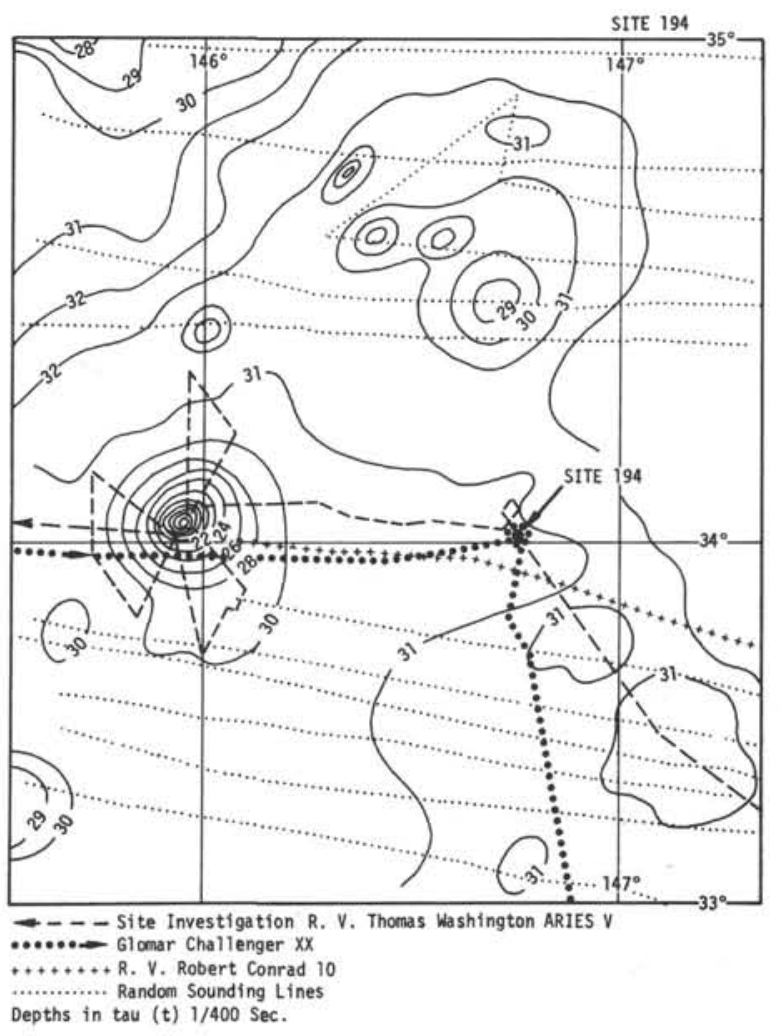

Figure 2. Bathymetry in the vicinity of Site 194 (based on various sounding lines). Contour interval 100 tau (1 tau $=1 / 400 \mathrm{sec}$ ). 
consolidated sediments. The results of Site 52 suggest that the situation may be more complicated, for at that site, drilling was terminated by a firm Cretaceous ash which lay within the upper transparent layer.

The more general objectives of this site were the determination of the age and early history of a segment of crust from which no previous age data were available, other than those provided by the superimposed Cretaceous seamounts. These flat-topped seamounts (guyots) were dredged on ARIES V, and a large quantity of shallow marine fossils of early Cretaceous age obtained.

The summits of these seamounts are about 4500 meters above their surroundings, establishing that the Lower Cretaceous Pacific was at least that deep at the time of their creation as volcanic islands. The Cretaceous deep-sea sediments in the area should provide independent evidence on the date of formation of the guyots. Their proximity, however, raises the disturbing throught that the volcanic event which created the volcanic pedestals may also have covered much of the surrounding area with lavas, which would obscure the early Mesozoic sediments and might never be penetrated by the drill or detected by the reflection seismograph.

\section{OPERATIONS}

The projected site was approached from the west and crossed at 0620 on 19 September 1971. The initial choice of the site by the Pacific Panel had been based on a profile taken along an east-west track by R/V Robert D. Conrad

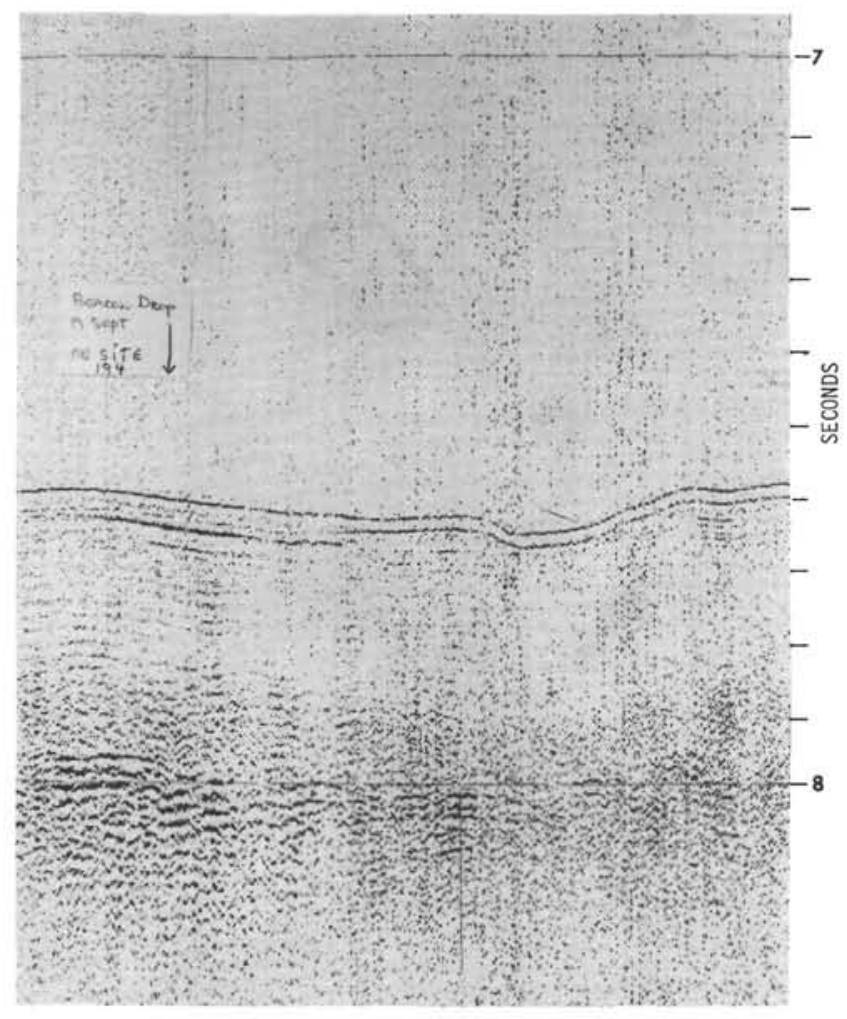

Figure 3. Glomar Challenger seismic profile across Site 194.
(Cruise 20). An investigation in June 1971 by R/V Thomas Washington (ARIES V) provided an additional seismic reflection record across the proposed site. Shortly after crossing the ARIES line, the ship reversed course and at 0710 the beacon was dropped while underway.

A repair of the Cat head air motor, difficulties in positioning, and the necessity of removing 14 questionable pipes from the string extended the time required to reach the mud line. The mud line was reached at 0830 on 20 September and Site 194 spudded in.

The first indication of bottom was observed on the weight indicator at 5775 meters. The corrected PDR depth (Matthews Tables and sea line to rig floor) was 5754 meters, and this figure was adopted as the mud line. Core 1 was taken 50 meters below the mud line in order to estimate the drilling characteristics of the sediment (see Table 1).

In view of the soft nature of the sediment cored, it was decided to wash ahead without a center bit. At 1450 and 5890 meters down, a slight resistance was noted and it was decided to take Core 2. The ship was rolling rather excessively $\left( \pm 15^{\circ}\right)$. The current and swell were coming from different directions, and the current was sufficiently strong that the thrusters could not supply sufficient thrust to hold against the current, and thus the ship had to take the swell on the beam and head into the current to remain on location. After taking Core 2, it was decided to wash ahead. At 5981.5 meters the drilling rate slowed slightly, and Core 3 was cut at approximately the depth of the top of the opaque layer. In cutting Core 3 , the bit plugged and the string was brought up six doubles. Circulation was restored and the string was lowered to complete the cutting of Core 3. Core 3 consisted of only a few chips of hard vitreous chert. The core barrel was sent back down to core ahead in an attempt to obtain fossil material for dating. Only 2.5 meters were drilled in over 3 hours. Mud was put in the hole to stabilize it, as increased torque was noted. When the overshot was sent down to bring up Core 4, the pin sheared-apparently, because chert had jammed the core barrel. On the second attempt, the core barrel was successfully recovered, but contained only a single lump of chert. The string was raised, circulation restored, and 7.4 meters were drilled. But in raising the string in preparation of coring, the hole filled. Several hours were expended drilling and pumping mud in an attempt to reach the previous maximum depth. The high and erratic torque was considered, however, to indicate such hazardous hole conditions that further attempts at coring or drilling were too risky. The options of drilling another hole at Site 194 or moving to another location to attempt to fulfill the objectives of the site were weighed. It was decided to move to a new site.

Site 194 was abandoned at 1630 on 21 September. Site 194 was drilled with a four-cone roller bit. Upon examining the bottom hole assembly at the start of operations on Site 195, a 10-inch-long longitudinal crack was discovered at the connection of one of the upper bumper subs. It can be assumed that water flowed through this crack reducing the water flow through the bit. The jet of water striking the side of the hole may have also contributed to the bad hole conditions which caused the abandonment of the site. 
TABLE 1

Coring Summary, Hole 194

\begin{tabular}{|c|c|c|c|c|c|c|c|c|c|c|c|}
\hline \multirow[b]{2}{*}{ Core } & \multirow{2}{*}{$\begin{array}{l}\text { Date } \\
\text { (Sep) }\end{array}$} & \multirow[b]{2}{*}{ Time } & \multicolumn{2}{|c|}{$\begin{array}{l}\text { Subbottom } \\
\text { Depth }(\mathrm{m})\end{array}$} & \multicolumn{2}{|c|}{ Total Depth (m) } & \multirow{2}{*}{$\begin{array}{c}\text { Cored } \\
(\mathrm{m})\end{array}$} & \multirow[b]{2}{*}{ Recovered } & \multirow[b]{2}{*}{ Age } & \multirow[b]{2}{*}{ Lithology } & \multirow[b]{2}{*}{ Paleontology } \\
\hline & & & Top & Bottom & Top & Bottom & & & & & \\
\hline 1 & 20 & 1155 & 37.5 & 47.0 & 5791.5 & 5801.0 & 9.5 & $8.5 \mathrm{~m}$ & Quaternary & $\begin{array}{l}\text { Pale green radiolarian } \\
\text { clay }\end{array}$ & Radiolaria \\
\hline 2 & 20 & 1700 & 142.0 & 151.5 & 5896.0 & 5905.5 & 9.5 & $6.5 \mathrm{~m}$ & Miocene & $\begin{array}{l}\text { Pale green radiolarian } \\
\text { clay }\end{array}$ & Radiolaria \\
\hline 4 & 21 & 0315 & 237.0 & 246.5 & 5991.0 & 6000.5 & 9.5 & $\mathrm{CC}$ & Cretaceous & Chert & Radiolaria \\
\hline 5 & 21 & 1105 & 246.5 & 248.0 & 6000.5 & 6002.0 & 1.5 & $\mathrm{CC}$ & Cretaceous & Chert & Radiolaria \\
\hline (6) & - & - & 256.0 & - & 6010.0 & - & - & Bit sample & Cretaceous & $?$ & Radiolaria \\
\hline
\end{tabular}

Note: Mud line is at 5754 meters.

\section{NATURE OF THE SEDIMENTS}

Five cores were attempted at Site 194 (Table 1, Figure 4). A total of 15 meters of sediment was recovered in Cores 1 and 2, while only core-catcher samples, consisting of chert fragments, were obtained from Cores 3,4 , and 5 . In addition, chert chips and a small amount of gray silty clay were recovered from the bit. Original sedimentary structures do not appear to have survived the drilling process in Cores 1 and 2 , most parts being greatly disturbed.

Interpolating between cored horizons and drilling records (Figure 5), the stratigraphy at this locality consists of approximately 230 meters of post-Cretaceous gray and brown silty clays containing radiolaria and diatoms, with volcanic ash intercalated. Cretaceous sediments show an abundance of chert, but poor sampling has left the associated lithologies other than chert essentially unsampled, although the presence of a few limestone fragments suggests that carbonate horizons may be present. Sedimentation rates of approximately $32 \mathrm{~m} / 10^{6}$ years for the Neogene and minimum values of $1 \mathrm{~m} / 10^{6}$ years for the Paleogene were calculated.

\section{Core 1 Sections 1-6 (37.5-47 meters)}

The succession is composed of gray noncalcareous, mottled, moderately stiff, silty clays rich in Radiolaria and diatoms. There is an abundance of volcanic ash throughout the core. Small pieces of white pumice occur in the top 150 $\mathrm{cm}$. Volcanic ash is present in thin layers $(0.1-10 \mathrm{~cm})$ and in small patches, which are either white, light gray, or green in color. The ashes consist for the most part of poorly sorted, angular, colorless glass shards with quartz and feldspar in minor amounts and accessory pyroxene. The proportion of glass in the ash zones usually exceeds $70 \%$. Glass shards are also scattered throughout the clays. Radiolaria from 52 meters were identified as Quaternary.

\section{Core 2 Sections 1-5 (142-151.5 meters)}

The sediment is a brown, firm to stiff clay, rich in Radiolaria and diatoms, with admixtures of volcanic material occurring either in distinct lumps or as part of the silt and clay fraction. Streaky variations in color (from yellow brown to dark brownish gray) occur throughout the core, indicating the high degree of distortion of the primary sedimentary structures as a result of drilling. At 181 and $514 \mathrm{~cm}$ pebbles occur which are composed of moderately indurated silty clay and silt, respectively. They probably represent altered pumice lapilli and volcanic ash. The pebble at $181 \mathrm{~cm}$ contains about $20 \%$ of palagonite, while the one at $514 \mathrm{~cm}$ has about $80 \%$ of authigenic calcite. Minor amounts of authigenic calcite also occur at 427 to $430 \mathrm{~cm}$. Traces of zeolites are also present. Radiolaria from 161 meters were identified as upper Miocene.

Cores 3 (227.5-237 meters), 4 (237-246.5 meters), 5 (246.5-248 meters), and Bit Sample at Total Depth (6010 meters)

From Cores 3, 4, and 5 only core-catcher samples were retrieved. They consist of dark brown to yellowish dense and tough chert fragments, all of them with the typical splintery to conchoidal fracturing. Several of the fragments are more or less distinctly thinly layered or laminated, most laminae only a few millimeters thick and wedging out after a few millimeters or centimeters. The boundaries between the laminae, which are more or less parallel, may be sharp and clearly visible, or the layers may grade into each other with cloudy and undulating contacts.

All dark specimens are of hardness greater than five, except four gray pieces from the core-catcher in Core 5, which can be scratched with a knife. They also do not reveal any sedimentary structures; however, they contain Cretaceous Radiolaria which are identifiable in thin sections. Radiolaria from the recovered bit, presumably at 6010 meters, gave a ? Cretaceous age.

\section{BIOSTRATIGRAPHIC SUMMARY} 194.

Only siliceous microfossils were recovered from Hole

\section{Cenozoic Sediments}

In Core 1 (37.5-47 meters below the sediment surface) radiolarians are few and silicoflagellates and diatoms rare. The radiolarians and silicoflagellates are well preserved and the diatoms moderately well preserved. In Core 2 (142-151.5 meters below the sediment surface) radiolarians 

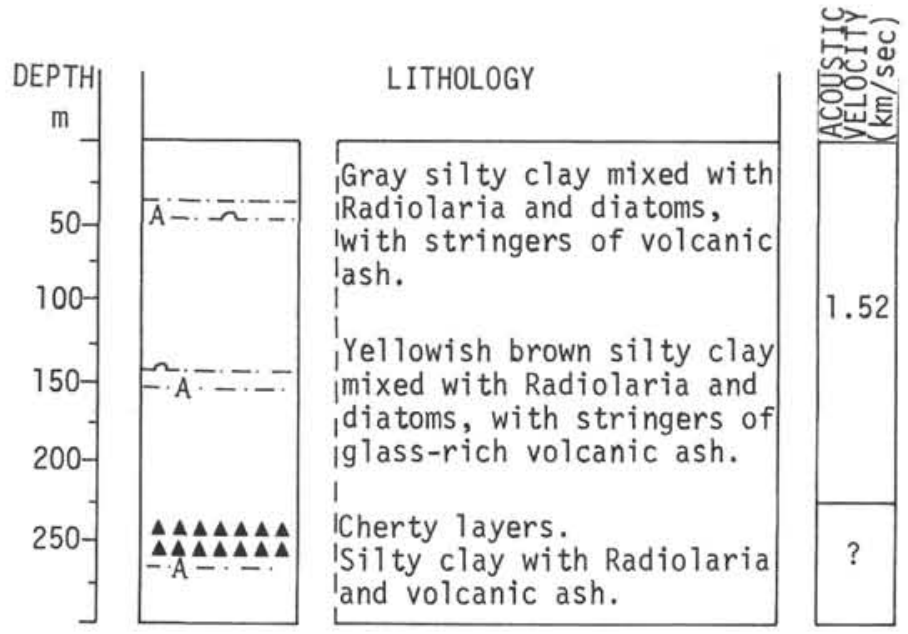

SITE 194

Figure 4. Generalized stratigraphy of Site 194.

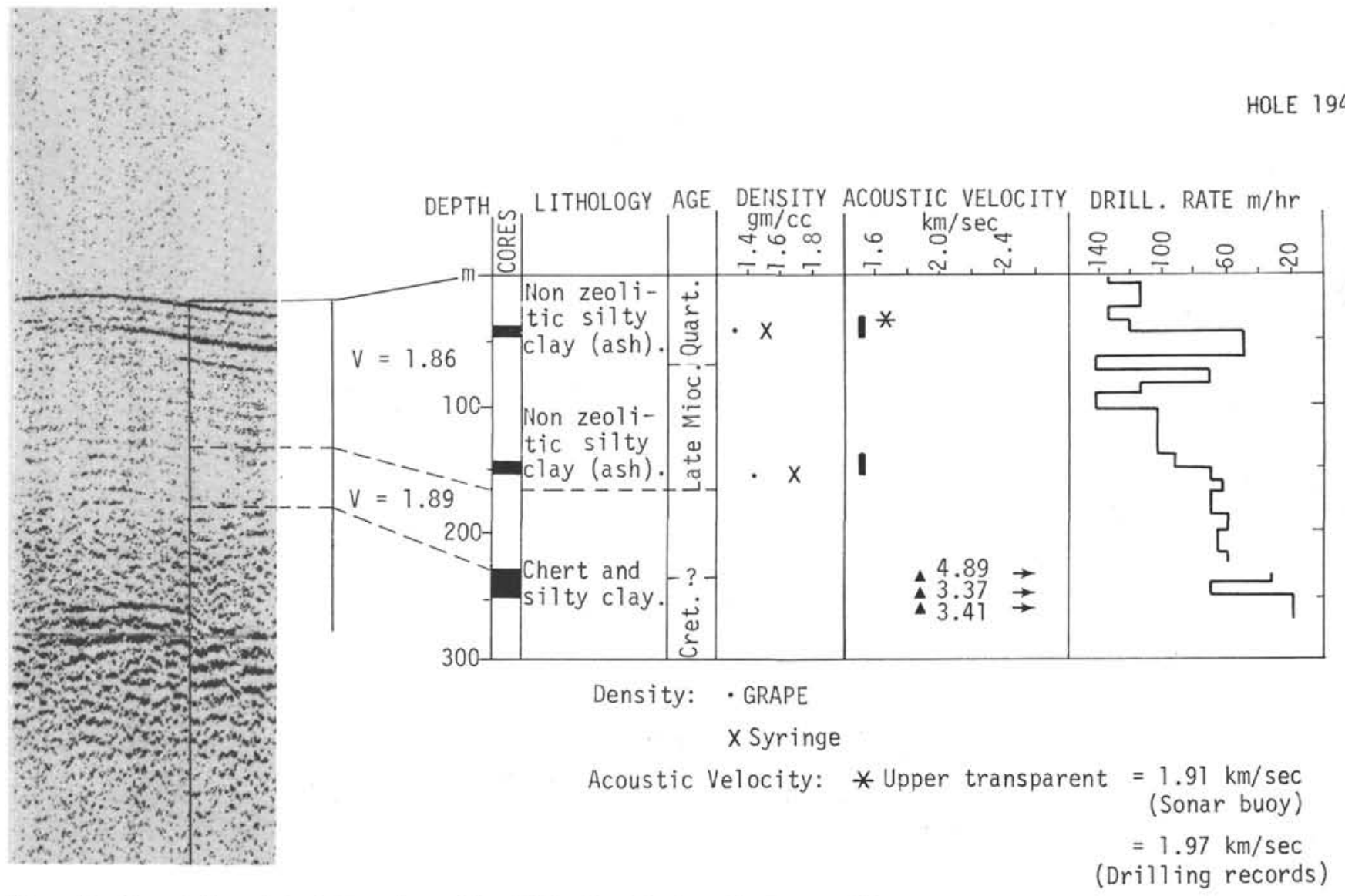

Figure 5. Correlation of drilled section at Site 194 with seismic reflection profile. 
are common to abundant, silicoflagellates few to rare, and diatoms common. All are well preserved.

If Hay's (1970) zonation for the north Pacific is applicable this far south as indicated by Kling (1971), the absence of Eucyrtidium matuyami and Lamprocyrtis heteroporos together with the presence of Stylacontarium acquilonium, Lamprocyrtis haysi, and Axoprunum angelinum suggest that Core 1 is early late Pleistocene in age (Axoprunum angelinum Zone). Also present are some rare tropical Quaternary forms, among them Spongaster tetras tetras. Among the silicoflagellates the presence of Dictyocha fibula var. aculeata throughout the core indicates a Pleistocene to Recent age, according to Ling (1972).

Core 2 (142-151.5 meters below the sediment surface) is below the range of the zonation established for the north Pacific, and age is here determined on the basis of a few forms whose ranges have been established in tropical sequences. The presence throughout of common Stichocorys peregrina and very rare Spongaster klingi?, together with, in the lower half of the core, very rare Ommatartus penultimus and $O$. avitus, indicates that this core is late Miocene (Stichocorys peregrina Zone). Among the silicoflagellates the navicular form of Dictyocha mutabilis is common, and Distephanus speculum var. pentagonus forma armatus and Dictyocha crux forma parva are very rare. The ranges for these silicoflagellates are not known, but the former two have been reported from the middle Miocene (Helvetian) and the latter from the early late Miocene.

\section{Mesozoic Sediments}

From Core 3 (at 227.5-237 meters), Core 4 (at 237-246.5 meters), and Core 5 (at 246.5-247 meters below the sediment surface), only core-catcher samples of chert were recovered. A dark brown chert sample from Core 3 yielded rare radiolarians, too poor to identify confidently. Presumably they are of Early Cretaceous age. Radiolarians in the white and red chert of Core 4 and the white and brown chert of Core 5 are common, moderately to poorly preserved, of Early Cretaceous age (Acaeniotyle tribulosa assemblage), younger than those in Core 196-3 which according to nannofossils is considered to be Valanginian to early Hauterivian. The bit sample at a total depth of 6010 meters (256 meters below the sediment surface) yielded a few poorly preserved radiolarians, presumably Early Cretaceous in age.

Biogenic components found in Site 194 cores are summarized as follows:

\section{Core 1:}

Foraminifera: none.

Nannofossils: none.

Radiolaria: The presence of Axoprunum angelinum and Lamprocyrtis haysi, together with absence of Eucyrtidium matuyami and Lamprocyrtis heteroporos indicate an early late Pleistocene age. (Axoprunum angelinum Zone).

Core 2:

Foraminifera: none.

Nannofossils: none.
Radiolaria: Stichocorys peregrina Ommatartus penultimus and $O$. avitus indicate a late Miocene age. (Stichocorys peregrina Zone).

Core 3:

Foraminifera: none.

Nannofossils: none.

Radiolaria: Poorly preserved, indeterminate Radiolaria only.

Core 4:

Foraminifera: none.

Nannofossils: none.

Radiolaria: In chert of the corecatcher: Staurosphaera amplissima, Acaeniotyle tribulosa, Triactoma cellulosa, and Dictyomitra leptoconica together with the absence of Sethocapsa trachyostraca and Staurosphaera septemporata indicate the Acaeniotyle tribulosa assemblage.

Core 5:

Foraminifera: none.

Nannofossils: none.

Radiolaria: In chert of the corecatcher: Acaeniotyle tribulosa, Triactoma cellulosa, Dictyomitra leptoconica, and $D$. (?) lacrimula together with the absence of Sethocapsa trachyostraca and Staurosphaera septemporata indicate the Acaeniotyle tribulosa assemblage.

\section{PHYSICAL PROPERTIES}

Shipboard measurements of bulk density and acoustic velocity are shown in Figure 6.

Bulk densities were determined by the GRAPE device and by the syringe method. Unfortunately, the syringe measurements were later found to be systematically in error because of faulty volume determinations, and the correct figures could not be recovered. In general, the density of the material at Site 194 above 160 meters seems quite low.

All samples for compressional velocity measurement were cut from relatively undisturbed and intact areas in the split core liner and given at least 4 hours to come to room temperature. The sonic velocities in the two cores recovered do not differ appreciably from that in seawater. However, the measured values are probably somewhat lower than in situ values due to drilling disturbance.

Sonic velocity measurements were also made on three pieces of chert recovered from the core catchers. The cherts at about 240 meters have an interestingly low acoustic velocity.

\section{CONCLUSIONS}

The thickening of the upper transparent acoustic layer observed on seismic reflection records is principally the result of a wedge of late Miocene to Quaternary ashy clays which are nearly $1 \mathrm{~km}$ thick on the east side of the Japan Trench off Tokyo, and which progressively thin eastward for 1000 to $1500 \mathrm{~km}$. This wedge of sediments, which was supplied from the island arcs and lands which border the Pacific Basin on the west, overlies a thinner, slowly deposited sequence of early Tertiary and Late Cretaceous abyssal clays which were apparently deposited without the influence of adjacent terrestrial and volcanic sources. 


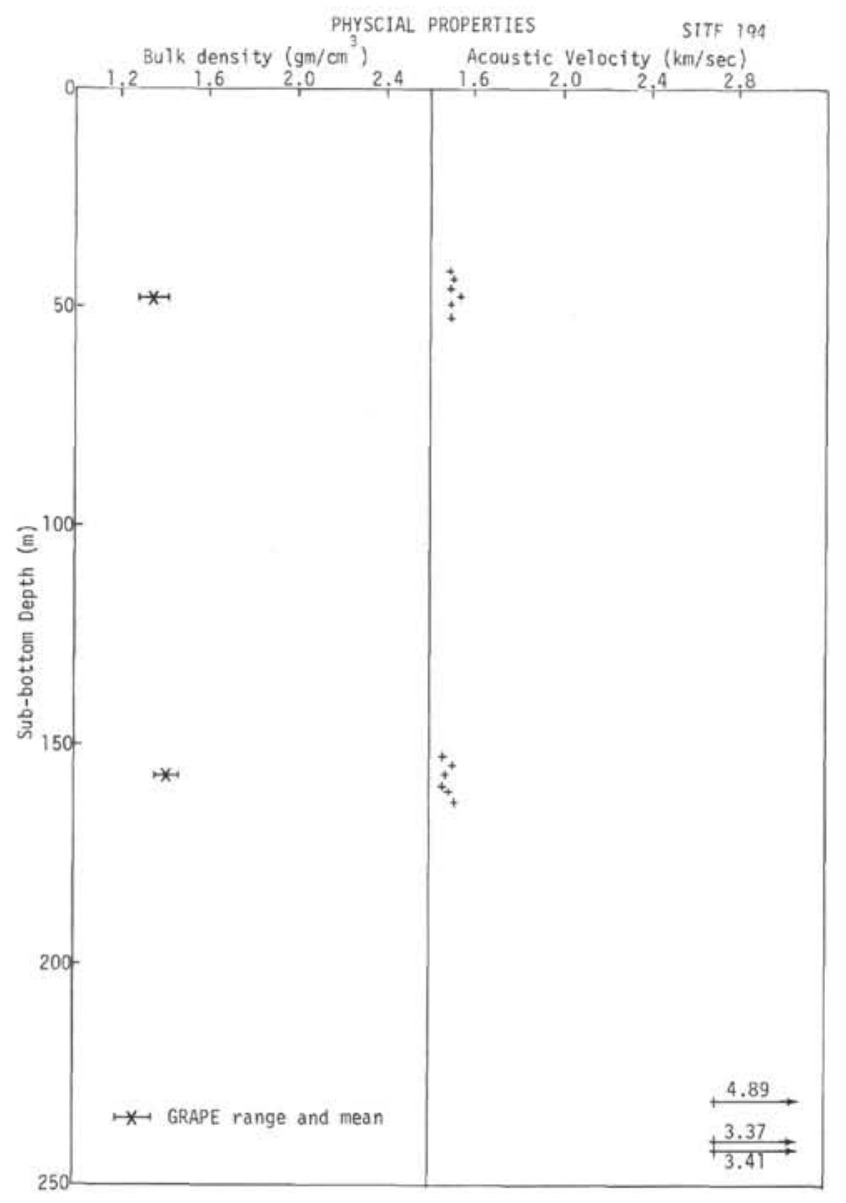

Figure 6. Measured values of bulk density and compressional sonic velocity at Site 194, plotted against depth below the sea floor.
The Pacific opaque layer at this site consists of cherts and clays of Cretaceous age.

\section{REFERENCES}

Hays, J. D., 1970. Stratigraphy and evolutionary trends of Radiolaria in north Pacific deep-sea sediments. Geol. Soc. Am., Mem., v. 126, p. 185-218.

Kling, S. A., 1971. Radiolaria: Leg 6 of the Deep Sea Drilling Project. In Fischer, A. G., Heezen, B. C., et al., Initial Reports of the Deep Sea Drilling Project, Volume VI: Washington (U.S. Government Printing Office), p. 1069-1117.

Ling, H.-Y., 1972. Upper Cretaceous and Cenozoic silicoflagellates and ebridians: Bull. Am. Paleontol., v. 62, p. 135-229. 


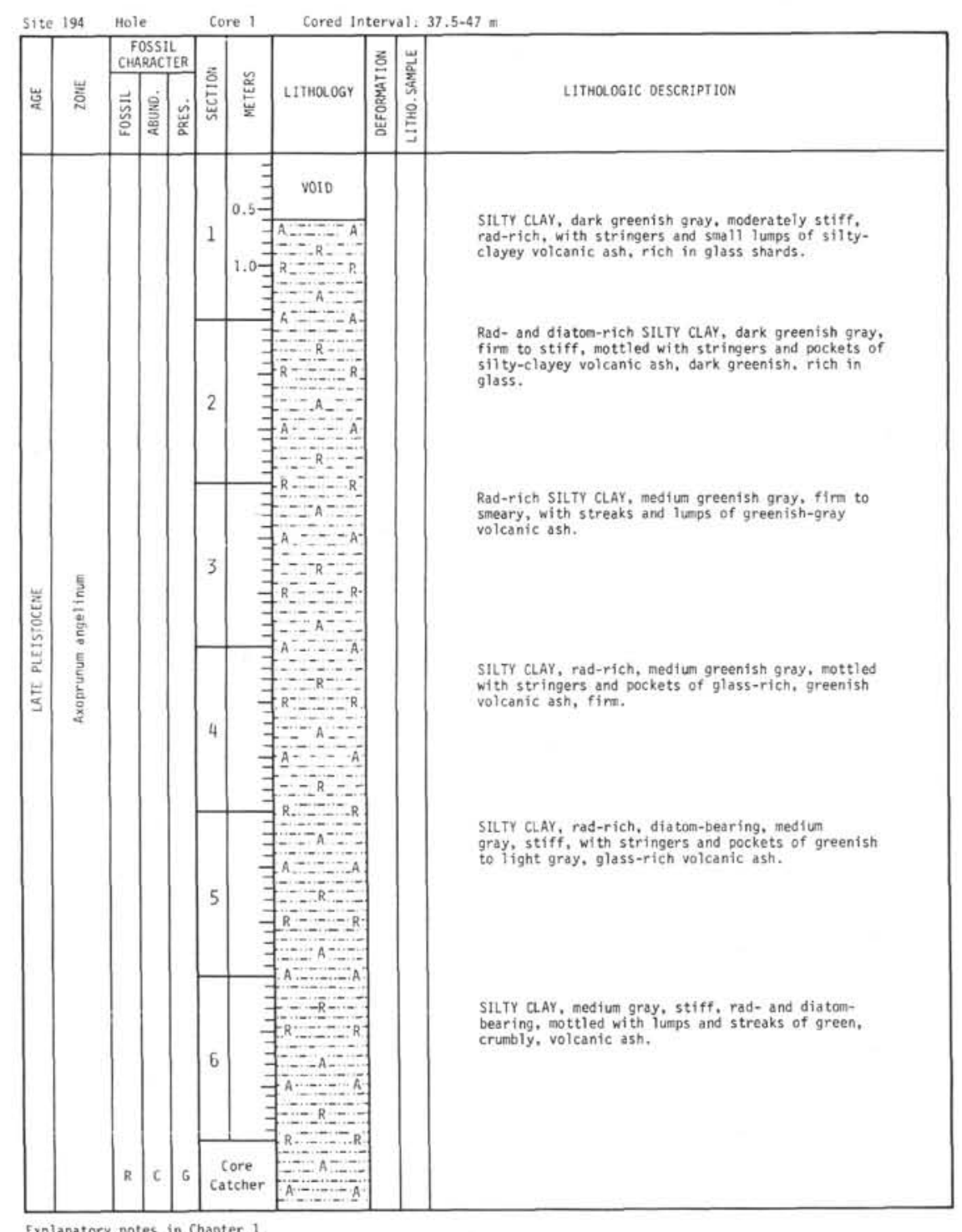

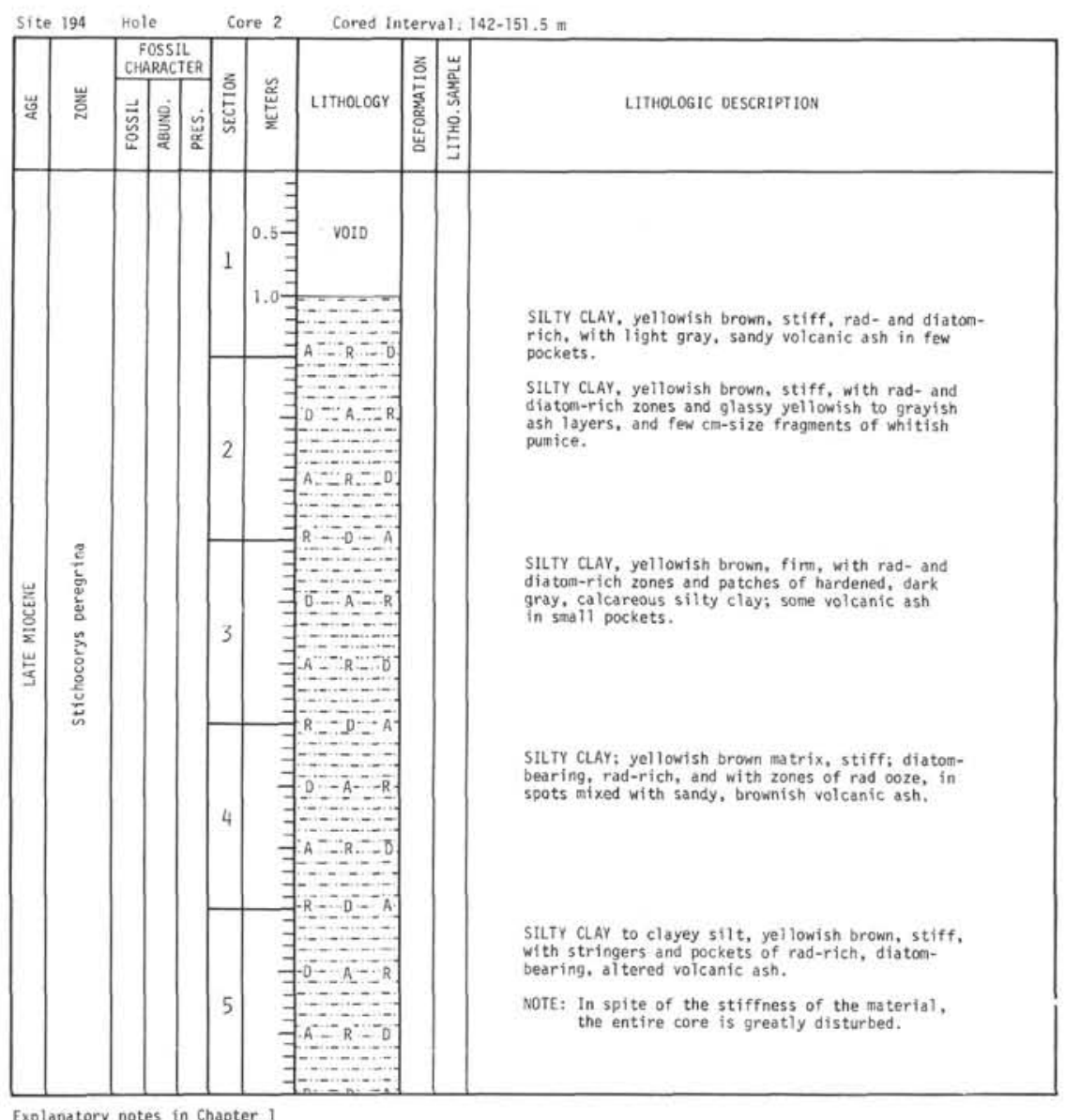




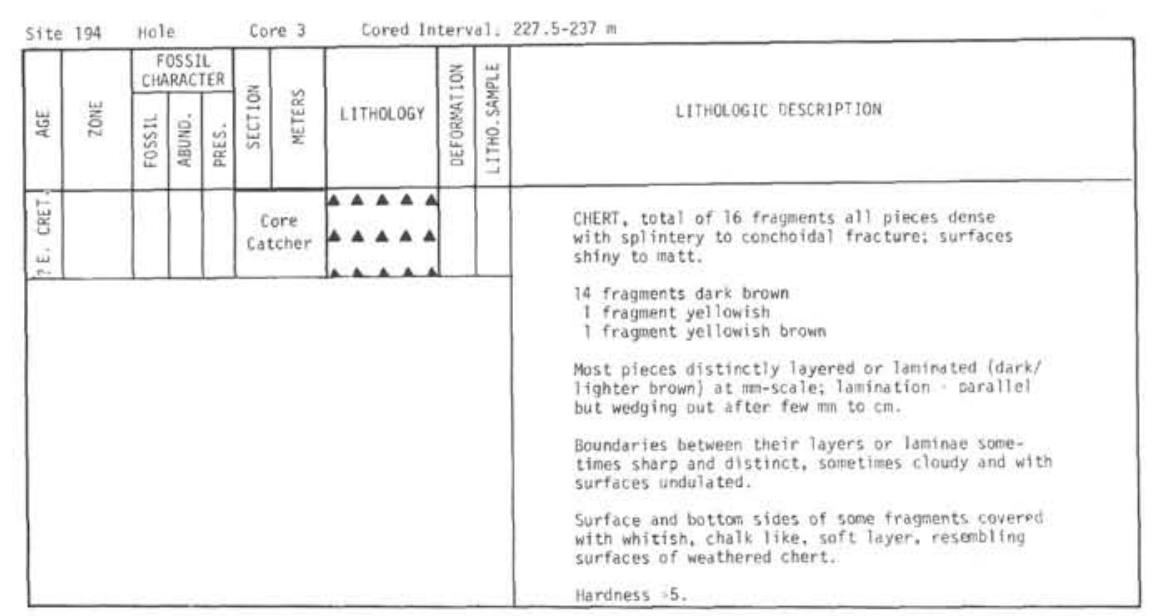

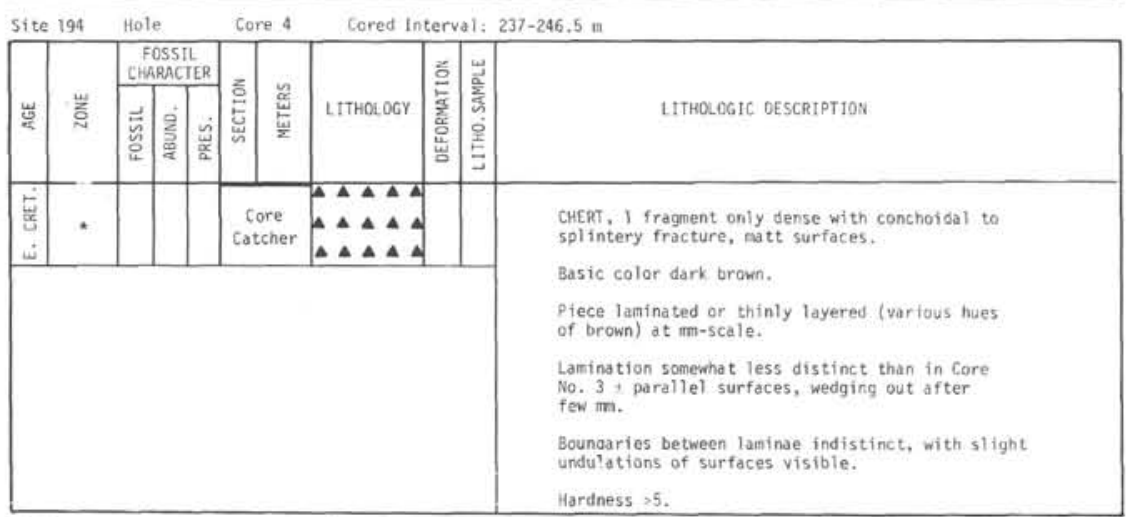

Explanatory notes in Chapter 1 *Acaeniotyle tribulosa assemblage

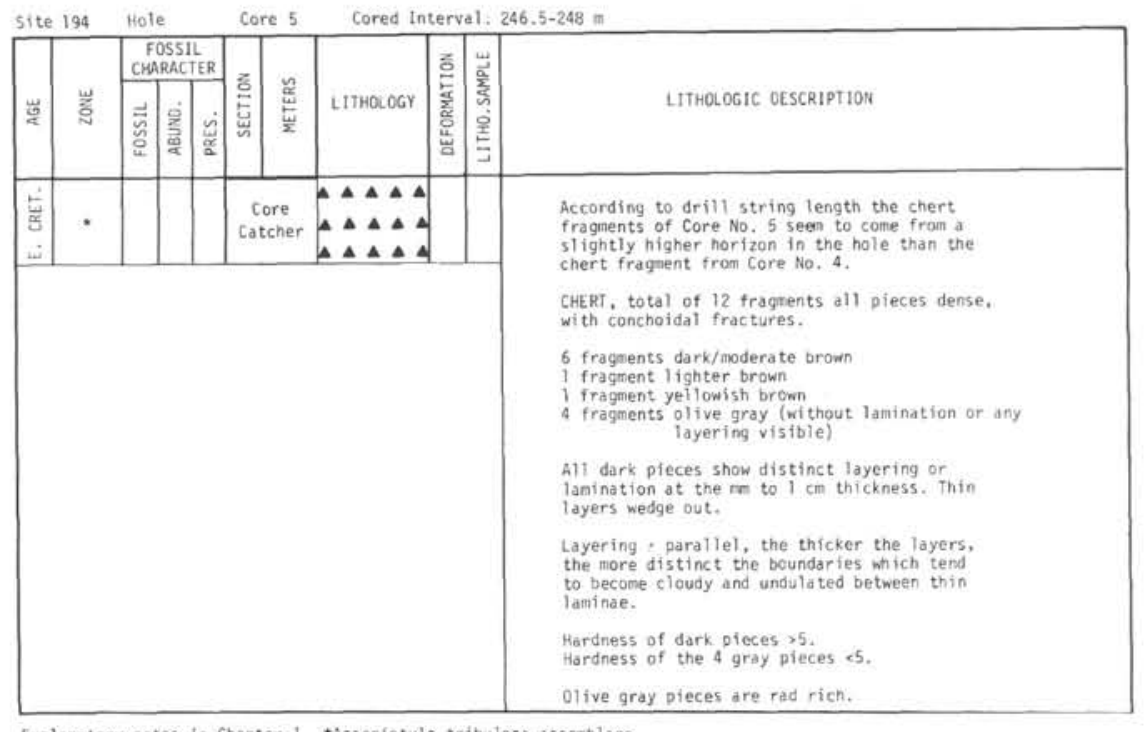

Explanatory notes in Chapter 1 *Acaenfotyle tribulosa asserblage

\begin{tabular}{|c|c|c|c|c|c|c|c|c|}
\hline \multirow[b]{2}{*}{ 荌 } & \multirow[b]{2}{*}{ 容 } & \multicolumn{3}{|c|}{$\begin{array}{c}\text { FOSSIL } \\
\text { CHARACTER }\end{array}$} & \multirow[b]{2}{*}{$\frac{\tilde{u}}{2}$} & \multirow[b]{2}{*}{ LITHOLOGY } & \multirow{2}{*}{ 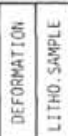 } & \multirow[b]{2}{*}{ LITHOLOGIC DESCRIPTION } \\
\hline & & & & 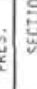 & & & & \\
\hline & & & & & $\begin{array}{l}\text { :ore } \\
\text { tcher }\end{array}$ & $=-1$ & & 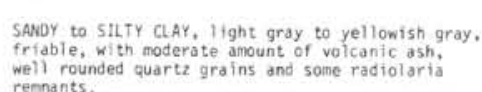 \\
\hline
\end{tabular}

Explanatory notes in chapter 1 
SITE 194

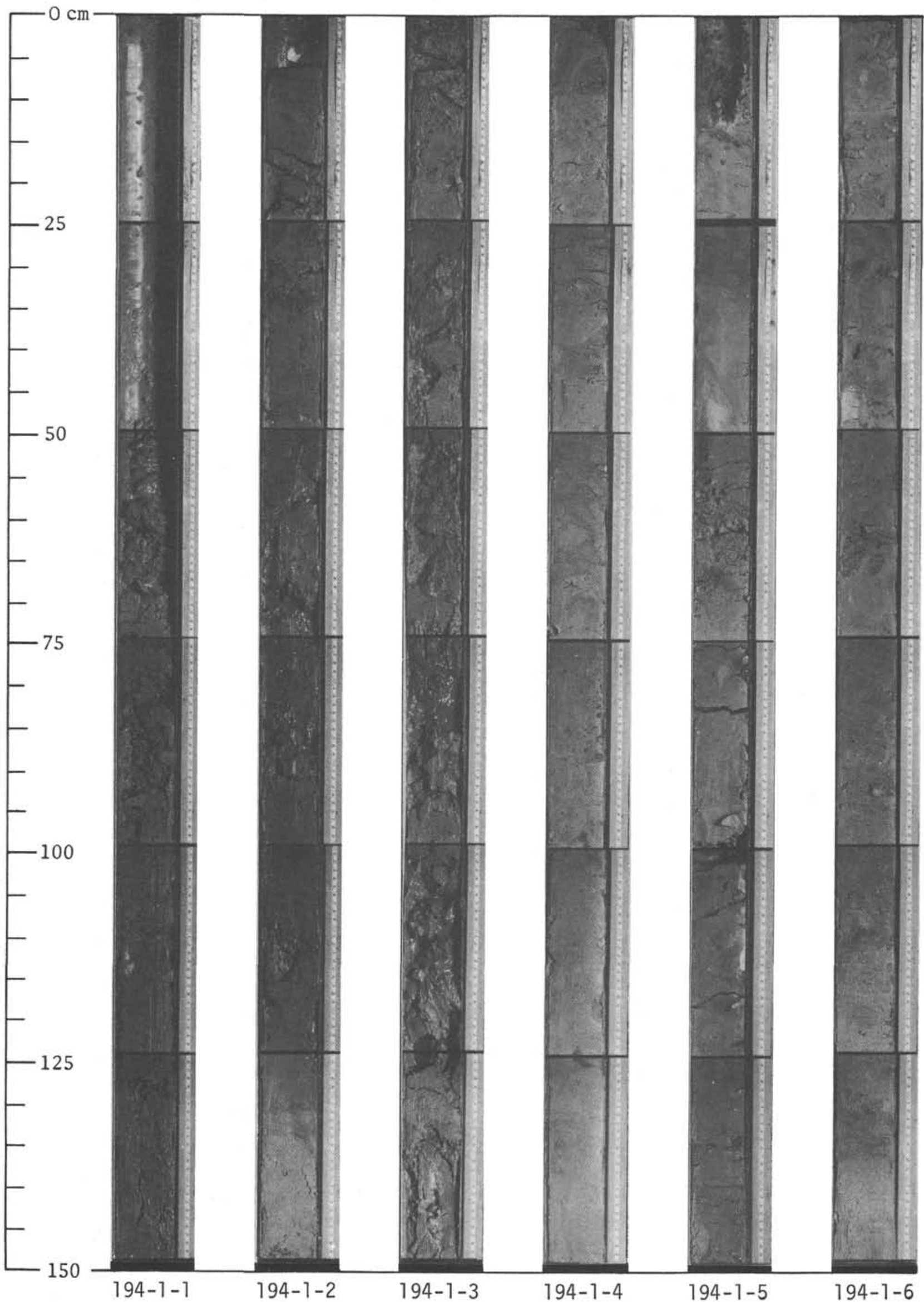




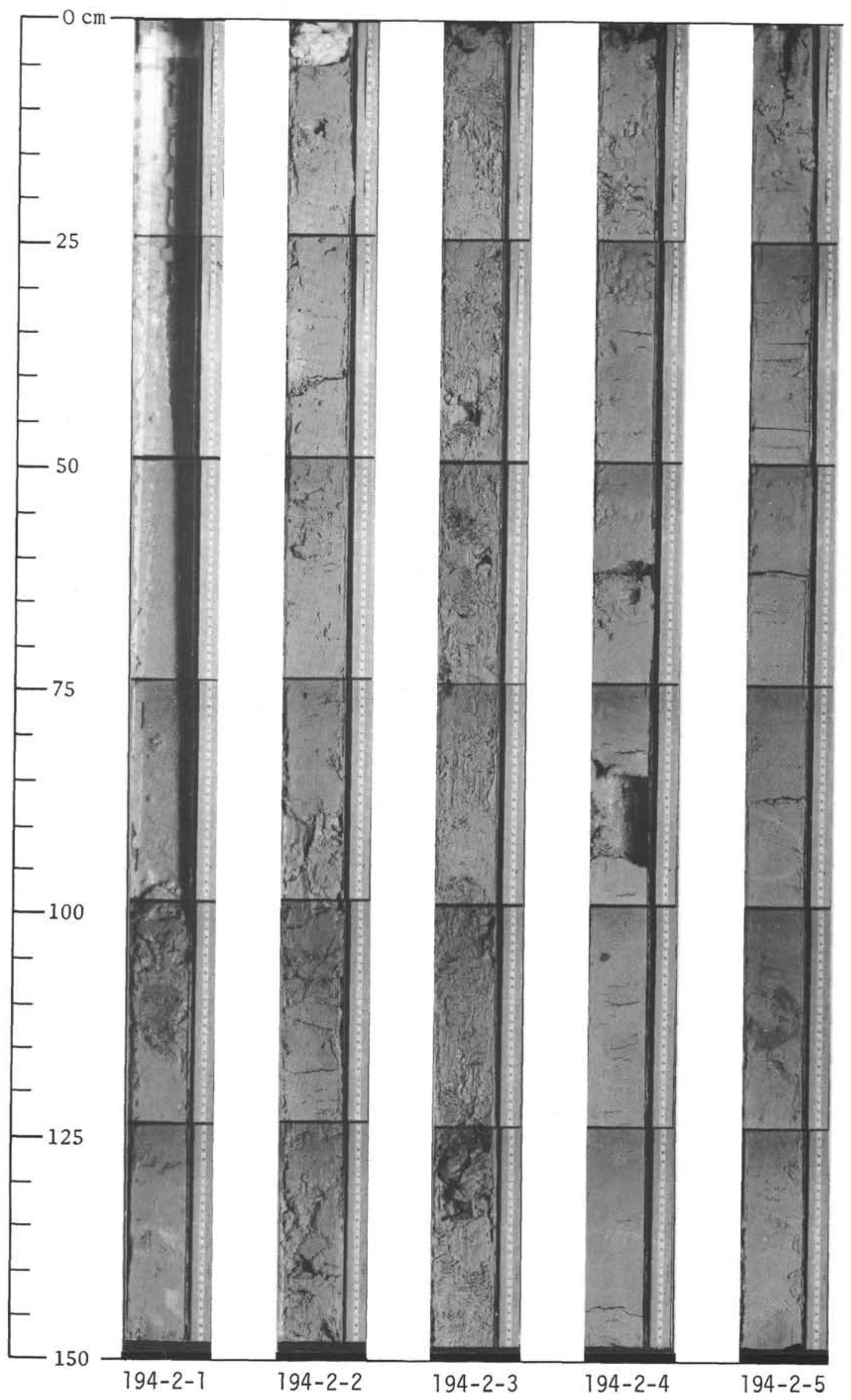

